\title{
LA UTOPÍA DEL BÁRBARO. IMÁGENES IDEALIZADAS DEL PASADO PRERROMANO EN LA ESPAÑA CONTEMPORÁNEA
}

\author{
The barbarian utopia. Idealizated pictures of pre-roman past in contemporanean \\ Spain
}

Tomás Aguilera Durán

Universidad Autónoma de Madrid

E-mail: tomas.aguilera@uam.es

Fecha de recepción: 7-III-2011

Fecha de aceptación: 8-IV-2011

RESUMEN: El tópico de la heroica resistencia hispana frente a Roma ha tenido un papel fundamental en el imaginario antiguo y moderno, procedente de la noción cínicoestoica del buen salvaje y perpetuado a través de la lectura humanista y positivista de las fuentes. Esta visión idealizada y esencialista se ha transformado y reinventado según el contexto histórico e ideológico de cada momento; se analizan algunos de los elementos que inciden en ese constructo cultural, en su dimensión antigua y moderna, y sus mecanismos de transmisión, y se profundiza en una de sus versiones más interesantes, su derivación en utopía socialista.

Palabras clave: Hispania prerromana, historiografía, mito del buen salvaje, utopía, identidad histórica, estereotipo cultural.

ABSTRACT: The topic of the heroic resistance of Iberians against Rome has played a key role in ancient and modern imagination, emerged from the cynic-stoic notion of the noble savage and perpetuated through humanistic and positivistic reading of sources. This essentialist and idealized vision has been transformed and reinvented by the historical and ideological context of each moment; we analyze some of the elements involved in this cultural construct, in their ancient and modern dimension, and their transmission mechanisms, and explore one of its most interesting versions, its derivation into a socialist utopia.

Key words: pre-Roman Hispania, historiography, myth of noble savage, historic identity, cultural stereotype. 


\begin{abstract}
El salvajismo es necesario cada cuatrocientos o quinientos años para revivificar el mundo (...). El mundo muere de civilización. Antes, en Europa, cuando los viejos habitantes de una hermosa comarca sentíanse debilitados, caían sobre ellos desde el Norte bárbaros gigantes que vigorizaban la raza. Abora, que ya no hay salvajes en Europa, son los obreros quienes realizarán esta obra en una cincuentena de años. Llamárase a esto la revolución social.
\end{abstract}

J. Martínez Ruiz, Azorín. Anarquistas Literarios, 1895.

\title{
1. UNA REFLEXIÓN SOBRE UN VIEJO TÓPICO
}

Es evidente que la tradición escrita que la Antigüedad nos ha legado de los pueblos periféricos del mundo clásico es un testimonio significativamente codificado, condicionado y enmarañado por datos cruzados, influencias y preconcepciones culturales, ideológicas y filosóficas, en mayor o menor medida deliberadas, que oscurecen una realidad de fondo que apenas podemos intuir. Tan interesante o más que acometer la tarea de desvelarlos, es la de indagar acerca de las formas en que esas imágenes con las que griegos y romanos representaron al otro se han mantenido vivas a lo largo del tiempo, condicionando nuestra propia perspectiva histórica, mutando el tópico antiguo en mito moderno. En esa indagación, se parte de la premisa de que no puede comprenderse plenamente ese mito moderno sin su origen antiguo, y viceversa, no es posible analizar el sentido del estereotipo antiguo sin considerar el legado que le ha conducido hasta nosotros.

En los siguientes apuntes, ese mito que se somete a reflexión es el de la retrospectiva idealizada del mundo prerromano hispano, entendida aquí esa heterogénea realidad como constructo más o menos monolítico en su proyección cultural simplificada y definida, en última instancia, según el prototipo helenístico del bárbaro occidental. Como por lo general se destaca, esa condición acarrea, como otras realidades periféricas de la ecúmene, el lastre de la caracterización especular, negativa y demonizada de los pueblos que la representan (salvajismo, violencia, inopia, crueldad...); pero lo cierto es que, al mismo tiempo y en determinados contextos, también se volcarían sobre su representación mental concepciones filosóficas e ideológicas positivas, idealizadas, incluso utópicas, que giran, fundamentalmente, en torno al arquetipo universal del buen salvaje, mecanismo de connotaciones escatológicas que sirve de evasiva crítica y contrapunto a los inconvenientes y excesos de la civilización del pensador antiguo.

En el otro extremo del hilo, tenemos la percepción de esos mismos pueblos, o mejor dicho, de ese mismo constructo cultural aglutinador que es el de los pueblos bárbaros, en su versión moderna y contemporánea. En ella vuelven a ser objeto sobre el que imaginar realidades paralelas ideales y utópicas, para ahora, además, construir identidades históricas que sirvan 
de precedente digno y memorable a las propias inquietudes, motivaciones y objetivos trascendentes.

En ese mundo bárbaro e incivilizado de la Iberia primitiva se van a proyectar, tanto en la Antigüedad como en su legado, tópicos que reconstruyan en cada momento las realidades ideales que se pretenden y anhelan. Un constructo de fondo, la imagen heroizada de la resistencia hispana frente a Roma, será el que predomine con mucho en esa imagen prototípica. Mucho se ha escrito ya sobre ella, tanto desde el punto de vista de la hermenéutica antigua como de la historiografía; poco se puede aportar al simple repaso del devenir de este concepto. Ahora bien, eludiendo la responsabilidad de la reflexión, se corre el riesgo de considerar este tópico como algo cerrado y monolítico meramente reiterado, cuando lo cierto es que sus múltiples ramificaciones y facetas son complejas y cambiantes a lo largo del tiempo.

El telón de fondo obligado va a ser la que podríamos considerar -sólo desde un punto de vista operativo- como la versión tradicional y fundamental del tópico, aquella que gira en torno a la percepción nacionalista de los pueblos prerromanos como heroicos libertadores de la patria, sintetizando lo que sabemos de su sentido en la Antigüedad y lo que representa en su reinvención moderna; sin detenernos mucho en ello, pues la bibliografía ya es abundante, servirá de punto de partida para profundizar en una de sus derivaciones contemporáneas más interesante aunque menos conocida, su reinterpretación como modelo de utopía socialista, incidiendo en las dimensiones antiguas y modernas de los elementos definidores de esta "versión alternativa". No se trata de dos modelos independientes: sus elementos constitutivos y su sentido de fondo están íntimamente ligados, ambos beben de los mismos topoi grecolatinos y la proyección de su acrítica lectura humanista y positivista; son versiones de un mismo legado. Su distinción responde a un ejercicio de deconstrucción sobre el que se pretende reflexionar, sin ser sistemático, acerca del proceso por el que distintas concepciones ideológicas, superpuestas a un mismo tópico, derivaron en dos nociones utópicas diferentes que nos dicen mucho sobre la evolución del pensamiento contemporáneo y el papel que la visión de la Antigüedad tiene en ella.

\section{REYES FilÓSOFOS y HÉROES SALVAJES}

Bien conocido es que dos eruditos griegos, Polibio y Posidonio, serán los primeros en transmitirnos de una forma sistemática y fruto de la vivencia directa su visión de la realidad ibérica; una visión que bajo formas insospechadas será de una trascendencia que excedería con mucho cualquier ambición. Los tópicos de la resistencia heroica de los pueblos hispanos, su entrega por la libertad, la carga simbólica de personajes como Viriato o de episodios como el asedio de Numancia o la toma de Sagunto, adquirirán en España, por distintas vías, alcance de auténtico mito nacional, convertidos 
en emblemas por excelencia de dignidad, libertad, victoria moral y honor. La idea de un pueblo austero, auténtico y puro, que se une para resistir frente a un enemigo sanguinario, retorcido y más fuerte, movido por la codicia, que somete y tiraniza, no deja de ser vista en el inconsciente colectivo, aún en la actualidad, como una realidad histórica incontestable y consustancial a la identidad hispana. El origen último de todo ello puede rastrearse en aquellos eruditos helenos ${ }^{1}$.

Comenzando por el principio, para comprender el origen de estos tópicos es imprescindible entender el contexto histórico e intelectual en el que se fraguan. La mentalidad con la que se acomete la representación de la Hispania de los siglos III y II a. n. e. hay que entenderla dentro del proceso de revitalización del género etnográfico en época helenística, resultado de la apertura de horizontes geográficos y culturales de la expansión alejandrina. Esta reinvención llevará consigo la recuperación de ciertos esquemas propios de la etnografía de tradición herodotea -como el determinismo geográficoaunque significativamente alterados: queda en parte superada ya la excesivamente cerrada concepción dicotómica del bárbaro del pensamiento clásico, con una perspectiva más abierta sobre el no griego influida de forma determinante por el eclecticismo filosófico propio del momento, en especial por las corrientes dominantes del cinismo y estoicismo; por otro lado, la nueva etnografía se verá fuertemente condicionada por los esfuerzos para dar sentido a la expansión imperialista romana en la que estos autores se integran y con la que, en mayor o menor medida, se identifican².

En este sentido, las primeras visiones sobre el indígena hispano resultan de la aplicación de ciertos modelos etnográficos que, lejos de representar a un bárbaro demonizado, dibujaron de él, en determinados contextos, una imagen positiva e idealizada de acuerdo con los sistemas filosóficos e ideológicos en los que se insertaba y que, por supuesto, no es excluyente de otros prejuicios peyorativos de corte etnocentrista ${ }^{3}$. Así por ejemplo, sobre la paradigmática figura de Viriato ${ }^{4}$, dos probables versiones,

1 Sobre el legado de estos autores en la historiografía: García Moreno, L. A. (1989), "La Hispania anterior a nuestra Era: verdad, ficción y prejuicio en la historiografía antigua y moderna", en Actas del VII Congreso Español de Estudios Clásicos, vol. III, Madrid: Universidad Complutense, pp. 17-43.

2 Sobre las concepciones geográficas y etnográficas helenísticas vid. Momigliano, A. ([1985] 1999), La sabiduría del bárbaro. Los límites de la belenización, México; Dihle, A. (1990), "Etnografía ellenistica", en Prontera, F. (ed.), Geografia e geografi nel mondo antico. Guida storica e critica, Roma-Bari: Laterza, pp. 173-199; Clarke, K. (1999), Between Geography and History. Hellenistic constructions of the Roman World, Oxford: Oxford University Press; Jacob, C. (2008), Geografia y etnografia de la Grecia antigua, Barcelona: Bellatera, pp. 137-213.

3 Gómez Espelosín, F. J., et alii (1995), La imagen de Hispania en la Antigüedad Clásica, Madrid: Gredos, pp. 109-157.

4 Sobre la figura de Viriato en la Antigüedad, con la ingente referencia bibliográfica previa, vid. García Quintela, M. V. (1999), Mitología y mitos de la Hispania indoeuropea., Madrid: Akal, 
la de Polibio y Posidonio, convergen convirtiéndole en el bárbaro idealizado por excelencia. En la versión polibiana, cuya pervivencia generalmente se identifica en Apiano $(I b .75)^{5}$, se presenta a un líder equitativo, que afronta los peligros de forma audaz y que es seguido por todos de manera voluntaria y entregada; aquí el fundamento del poder de Viriato aparece codificado según un principio antropológico clásico que define el paso de una jefatura primitiva, mantenida por la fuerza, a una jefatura de consenso, lograda cuando el líder es capaz de asumir como suyos los peligros y necesidades de la comunidad ${ }^{6}$. De esta manera Polibio estaba dando explicación al potencial de liderazgo de Viriato según los principios teóricos sobre los que se asentaba su formación. Al mismo tiempo, y desde un prisma más amplio, se acepta de forma generalizada que la representación dignificada que el megapolitano ofrece de la resistencia hispana frente a la peyorativa de la acción romana en algunos episodios, tiene mucho que ver con su animadversión hacia ciertas figuras como las de Galba, Lúculo o Didio, representantes de los círculos contrarios al grupo de los Escipiones, a los que está personalmente ligado y que son objeto de exaltación en su obra.

Por su parte Posidonio, más allá de las informaciones recibidas del primero, aplicaría sobre el bárbaro hispano su propiay bien trabada concepción filosófica cínico-estoica del mundo, de la que se deriva la representación moralmente positiva del salvaje como contrapunto a la corrupción de una civilización degradada, superficial y codiciosa ${ }^{7}$. Así se explica que Diodoro, considerado como uno de sus principales transmisores 8 , alabe la habilidad y resistencia de celtíberos y lusitanos (V 33 y 34) o la cultura de los vacceos

pp. 177-222; Sánchez Moreno, E. (2001), “Algunas notas sobre la guerra como estrategia de interacción social en la Hispania prerromana: Viriato, jefe redistributivo (I)", Habis 32, pp. 149-169; id. (2002), "Algunas notas sobre la guerra como estrategia de interacción social en la Hispania prerromana: Viriato, jefe redistributivo (y II)", Habis 33, pp. 141-174; Pastor Muñoz, M. (2004), Viriato. El héroe hispano que luchó por la libertad de su pueblo, Madrid: La Esfera de los Libros; Pérez Abellán, J. A. (2006), "Problemática en torno al estudio de la figura de Viriato", Panta Rei 1, $2^{a}$ época, pp. 45-56.

5 Hay quien la identifica también en Diodoro: De Hoz Bravo, J. J. (2000), "La etnografía de los pueblos de Iberia en Diodoro v 33-34 y el problema de sus fuentes”, en Alganza, M. (coord.), Epieikeia: Studia graeca in memoriam de Jesús Lens Tuero, Granada: Athos-Pérgamo, pp. 221-238.

6 García Moreno, L. A. (2002), "Polibio y la creación del estereotipo de lo Hispano en la etnografía y la historiografía helenísticas", Polis 14, pp. 127-146 [reeditado en Santos, J. y Torregaray, E. (eds.) (2005), Polibio y la Península Ibérica, Vitoria-Gasteiz: Universidad del País Vasco, pp. 138-141].

7 García Fernández, E. (2002), "La visión estoica de Iberia", en Hernández, L. et alii (eds.), Actas del I Congreso Internacional de Historia Antigua. La Peninsula Ibérica hace 2000 años, Valladolid, pp. 699-705.

8 Sobre la aportación de Diodoro y el debate en torno al peso de Polibio y Posidonio en su obra vid. De Hoz, op. cit., pp. 221-238. 
(V 34), nos recalque su hospitalidad (V 34) o se lamente por las condiciones de trabajo de colonos y esclavos en las minas (V 36 y V 38). Volviendo a Viriato, el personaje que nos presenta Diodoro (XXXIII 1) responde al prototipo perfecto del rey primitivo ideal de la filosofía cínico-estoica: criado en la austeridad y ascesis de la naturaleza, justo y caritativo, ajeno al lujo y la riqueza material, sabio pero no corrompido por la educación reglada, atribuyéndole en alguno de sus discursos, incluso, de manera totalmente descontextualizada, fábulas de corte cínico que desvelan sin lugar a dudas el modelo de fondo?

Si bien Estrabón, deudor forzoso de los dos anteriores, omitirá esas imágenes idealizantes de la resistencia hispana, que es denigrada en su discurso de legitimación romana casi incondicional ${ }^{10}$, sí fraguarán en algunos de sus coetáneos, como el mentado Diodoro, y toda la literatura grecolatina posterior. De hecho, la imagen tópica de la entrega guerrera de estos pueblos por su libertad, que les lleva a preferir la muerte al sometimiento, se convertirá en una de las ideas más reiterativas de la historiografía imperial, trasladándose automáticamente de unos escenarios a otros con evidente licencia literaria, potenciando su contenido épico y dramático, exaltando por oposición la victoria romana y desprovistos ya del sentido inicial ${ }^{11}$.

En definitiva, entre la ingente cantidad de tópicos negativos que salpicarán la visión del bárbaro hispano, sobreviviría parte de una primigenia reconstrucción del indígena como noble defensor de su independencia y buen salvaje, inocente, auténtico y virtuoso, en origen pretexto para el desarrollo de ciertas nociones filosóficas e ideológicas, convertido después en un superficial cliché literario que será el que-predomine en la visión moderna de estos pueblos.

Ciertamente, la historiografía moderna española -como la portuguesa ${ }^{12}$ no ha podido sustraerse de esas imágenes ideales emanadas de las fuentes clásicas, por las propias inercias de la reiteración, sin duda, pero también

9 Lens Tuero, J. (1986), "Viriato, héroe y rey cínico", Estudios de Filología Griega 2, pp. 253-272 [reeditado en Id. (ed.), Estudios sobre Diodoro de Sicilia, Granada: Universidad de Granada, pp. 127-144]; García Moreno, L. A. (1988), "Infancia, juventud y primeras aventuras de Viriato, caudillo lusitano", en Actas del I Congreso Peninsular de Historia Antigua (Santiago, 1986), vol. II, Santiago de Compostela: Universidad de Santiago de Compostela, pp. 373-382 [reeditado en Id. (2001), De Gerión a César. Estudios históricos y filológicos de la España indígena y romanorepublicana, Alcalá de Henares: Universidad de Alcalá, pp. 139-152].

10 Sobre la visión estraboniana de Iberia con la bibliografía previa vid. Gómez Espelosín, F. J. (ed.) (2007), Geografía de Iberia. Estrabón, Madrid: Alianza.

11 Algunos de los episodios paradigmáticos serán los de Numancia, Segeda o Sagunto, entre otros (Gómez Espelosín et alii, op. cit., pp. 120-121).

12 Garcia, J. M. (1985), "Viriato: uma realidade entre o mito e história”, Prelo 9, pp. 59-70; Guerra, A. y Fãbiao, C. (1992), "Viriato: Genealogia de um Mito", Penélope. Fažer e desfazer a História 8, pp. 9-23. 
por lo que contienen de implicación emocional, perviviendo en la imagen colectiva de la conquista romana una noción dicotómica entre conquistadores y sometidos, usurpadores y resistentes, que en el fondo no es más que la proyección histórica de arquetípicas identidades ${ }^{13}$. Desde el Renacimiento, la resistencia hispana frente a la invasión extranjera, vista en general como pervertidora de la esencia española, fue uno de los tópicos por excelencia de la genealogía mítica nacional, comprendida como manifestación del espíritu heroico de lo español transmitido a lo largo de los siglos ${ }^{14}$; ningún ejemplo tan ilustre y trascendente como la Numancia de Miguel de Cervantes:

\section{Indicio ba dado esta no vista hazaña \\ del valor que en los siglos venideros \\ tendrán los bijos de la fuerte España,}

bijos de tales padres herederos ${ }^{15}$.

Esa tónica esencialista en clave bélica alcanzará su apogeo, sin rupturas, entre los siglos XVIII y XIX, cuando tome su forma nacionalista definitiva, plasmándose nítidamente tanto en la historiografía -con Modesto Lafuente como máximo representante-, como en el discurso político o el arte ${ }^{16}$. Quizá los ejemplos más reconocibles sean los brindados por la pintura de Historia, que nace del propio contexto ideológico de la Guerra de Independencia ( $\mathrm{La}$ muerte de Viriato, José Madrazo, 1808), y que tendrá su apogeo en la segunda

13 Wulff Alonso, F. (2007), “¿Unidos contra Roma? Notas historiográficas sobre identidades europeas y Mundo antiguo a partir del caso español”, Revista de historiografía 6, pp. 14-29; Sánchez Moreno, E. y Aguilera Durán, T. (e.p.), "Bárbaros y vencidos, los otros en la conquista romana de Hispania. Notas para una deconstrucción historiográfica", en García, E. B. y Cid, R. M. (eds.), Homenaje al profesor Julio Mangas Manjarrés, Madrid-Oviedo: Universidad Complutense de Madrid y Universidad de Oviedo.

14 Wulff Alonso, F. (2003), Las esencias patrias. Historiografía e historia antigua en la construcción de la identidad española (siglos XVI-XX), Barcelona: Crítica, pp. 23-60; no sin contradicciones con la positiva percepción imperialista de Roma: Id., pp. 29-35 y 76-90; Jimeno, A. y de la Torre, J.I. (2005), Numancia, simbolo e bistoria, Madrid: Akal, pp. 58-63 y 106-111.

15 Cervantes Saavedra, M. ([1585] 2003), La Numancia, Universidad de Alicante-Banco Santander, edición digital (http://cervantesvirtual.com), Jornada IV, pp. 99-100. Acerca de la visión del mito numantino en los siglos XVI y XVII vid. Álvarez Martí-Aguilar, M. (1997), "Modelos historiográficos e imágenes de la Antigüedad: El Cerco de Numancia de Miguel de Cervantes y la historiografía sobre la España antigua en el siglo XVI", Hispania Antiqua 21, pp. 545-570; Jimeno y de la Torre, op. cit., pp. 53-103.

16 Wulff (2003), op. cit., pp. 97-124; Jimeno y de la Torre, op. cit., pp. 113-118, 130-133 y 143147; Quesada Sanz, F. (1996), "La imagen de la Antigüedad hispana en la plástica española del siglo XIX”, en Olmos, R. (ed.), Al otro lado del espejo. Aproximación a la imagen ibérica, Madrid: Pórtico, pp. 211-238; García Cardiel, J. (2010), "La conquista romana de Hispania en el imaginario pictórico español (1754-1894)", Cuadernos de Prehistoria y Arqueología de la Universidad Autónoma de Madrid 36, pp. 131-157. 
mitad del siglo, vinculada a la consolidación del nacionalismo liberal (El último día de Numancia, Alejo Vera, 1881 o Viriato, Ramón Pedró y Pedret, 1882 , entre muchos). En este sentido, muy ilustrativa, por fecha y oportunidad histórica, es la retórica del jurista F. Martínez Marina en su Discurso sobre el origen de la monarquía y sobre la naturaleza del gobierno español, preludio de su Teoría de las Cortes de 1813, obra fundamental y pionera del liberalismo español; antes de dedicar unas páginas a la antigua epopeya hispana proclama:

España fue uno de los países donde así como en nativo suelo se han conservado y han florecido más bien que en otro alguno estas virtudes heroicas. Por lo menos es cierto que los españoles no cedieron a ninguna nación del universo en amor por la libertad, $y$ acaso sobrepujaron a todas en fortaleza y constancia para defenderla ${ }^{17}$.

Aunque este tópico absolutamente anacrónico empezará a mostrar signos de agotamiento desde finales del XIX -aun perpetuado, ya trasnochadamente, en la obra de A. Schulten ${ }^{18}$, y a pesar de los intentos por reinventarlo en el gozne del siglo XX (vid. infra), los más ancestrales estereotipos se reactivarán tras la Guerra Civil, entendiéndose la artificiosa victoria moral hispana como pretendido trasunto del triunfante Movimiento Nacional y el prototípico Viriato hispano -que no lusitano-, como una proyección más del Caudillo, reproduciéndose de nuevo, en la retórica y la educación españolas, las más simplistas y patrioteras estampas decimonónicas ${ }^{19}$.

\section{NOBLES LADRONES Y BÁRBAROS COMUNISTAS}

Con un bagaje tan fundamentalmente continuista $-\mathrm{y}$ tan profusa $\mathrm{y}$ convenientemente estudiado-, la excepción, la desviación de la norma, por anecdótica que ésta pudiera ser, merece cuando menos una cierta reflexión. Lo cierto es que al calor del convulso ambiente intelectual del cambio del siglo XIX al XX ${ }^{20}$, como derivación del espíritu de ruptura propio de la crisis de valores del momento, se fraguaría una interesante reelaboración tardía del mito de la épica resistencia hispana. La pionera obra del jurista reformador Joaquín Costa renegará por primera vez de las preconcepciones esencialistas y nacionalistas más conservadoras, poniendo en tela de juicio algunas de las imágenes legadas por las fuentes clásicas, para configurar un nuevo

17 Martínez Marina, F. X. (1813), Discurso sobre el origen de la monarquía y sobre la naturaleza del gobierno español: para servir de introducción a la obra Teoría de las Cortes, Madrid, p. 64.

18 Wulff Alonso, F. (2004), "Adolf Schulten. Historia antigua, arqueología y racismo en medio siglo de historia europea", en id. (ed.), Historia de Numancia, de Adolf Schulten, Pamplona: Urgoiti, pp. IX-CCXLI.

19 Wulff (2003), op. cit., pp. 225-253; Wulff, F. y Álvarez Martí-Aguilar, M. (eds.) (2003), Antigüedad y franquismo (1936-1975), Málaga: Diputación de Málaga.

20 Acerca de la historiografía de este período vid. Wulff (2003), op. cit., pp. 125-185. 
discurso histórico radicalmente distinto en lo que al sistema interpretativo se refiere, aunque esencialmente convergente con el viejo modelo en tanto que perpetúa, bajo una nueva mirada, la idealizada percepción del pasado anterromano como constructo en el que proyectar la propia visión utópica de la realidad. Siendo aparentemente la interpretación de Costa un verdadero unicum en el momento y en los términos en que la formula, su avanzado planteamiento tendrá una fundamental repercusión historiográfica que, sin embargo, no ha sido siempre suficientemente valorada ${ }^{21}$.

Para entender esta nueva imagen hay que incidir necesariamente en un tema sólo circunstancialmente aludido hasta ahora, el del célebre bandolerismo hispano. Largamente se ha debatido el sentido que este fenómeno, absolutamente tópico en las fuentes clásicas, tuvo en las sociedades prerromanas de la Iberia indoeuropea ${ }^{22}$. La caracterización de los pueblos hispanos -especialmente lusitanos y pueblos del norte- como meras bandas dirigidas por cabecillas sembrando el caos en los llanos y causando estragos en los ejércitos romanos, con el anárquico golpe de mano como única táctica militar, es un estereotipo que parece proceder en buena parte, de nuevo, de los primeros testimonios históricos sobre la Península Ibérica. Por un lado, parece ser la confluencia de dos tópicos, el primitivismo cultural y el rudimentario uso de la guerra -frente al reglado bellum iustum-, omnipresentes en la caracterización polibiana, y por supuesto posterior, del bárbaro occidental ${ }^{23}$. Por otra parte, probablemente juegue un papel importante el determinismo geográfico de Posidonio, según el cual, las regiones montañosas y agrestes inclinan a sus habitantes de forma natural a la práctica del pillaje como forma de vida, sin que ello parezca conllevar en este autor tinte peyorativo alguno ${ }^{24}$. Este marco de fondo, que procede en última instancia de un antiguo cliché antropológico griego recurrente en la caracterización del bárbaro primitivo, agreste y nómada ${ }^{25}$, será el heredado

21 Sobre las aportaciones de J. Costa a la Historia Antigua vid. Blázquez Martínez, J. Ma (1987), "Joaquín Costa y la Historia de la España antigua", Anales de la Fundación Joaquín Costa 4, pp. 119-138; García Quintela, M. V. (1999), Mitología y Mitos de la Hispania indoeuropea III, Madrid: Akal, pp. 54-56; Wulff (2003), op. cit., pp. 138-141.

22 Visiones actualizadas de la cuestión y referencia a la abundantísima bibliografía previa en Sánchez Moreno, E. (2006), "Ex pastore latro, ex latrone dux... Medioambiente, guerra y poder en el Occidente de Iberia”, en Ñaco, T. y Arrayás, I. (eds), War and territory in the Roman World, Oxford: BAR, pp. 55-79; García Quintela, M. V. (2007), "Estrabón y la etnografía de Iberia”, en Gómez, F. J. (ed.), Geografía de Iberia. Estrabón. Madrid: Alianza, pp. 96-105. También interesante Gómez Fraile, J. M. (1999), "Mercenariado y bandolerismo en Celtiberia. Dos cuestiones desenfocadas", en Burillo, F. (ed.), IV Simposio sobre los Celtíberos. Economía. Homenaje a J.L. Argente Oliver, Zaragoza, pp. 503-509.

23 Ciprés Torres, P. (1993), Guerra y sociedad en la Hispania indoeuropea. Vitoria: Universidad del País Vasco, pp. 43-50.

24 García Fernández, op. cit., p. 703.

25 Ciprés, op. cit., pp. 97-147; Sánchez Moreno (2006), op. cit., pp. 57-59. 
por Estrabón, haciendo de él un elemento esencial de su concepción etnográfica de los pueblos peninsulares (III 3.5 y 8; 4.5 y 15), vinculando el fenómeno del bandolerismo al atraso cultural del bárbaro ibérico y su natural inclinación por la violencia y la anarquía. Aparte del probable contenido histórico real que pueda extraerse de estas fuentes - para lo que se remite a la mencionada bibliografía-, lo que parece patente es que en el discurso de la conquista y, sobre todo, en la retórica augustea, se simplificó y generalizó este concepto etnográfico convirtiéndolo en mecanismo de denigración del hispano y legitimación de la intervención militar y cultural romana. Ésta será la imagen que se perpetúe en los autores coetáneos y posteriores ${ }^{26}$, y en la que se incluye toda la tradición viriática.

Como parte de las contradicciones con las que la historiografía moderna de los siglos XVI-XVIII tendrá que bregar en su discurso imperialista -con las que se reencontrará el franquismo-, tales como su ambigua actitud ante los romanos -unificadores pero extranjeros-, la desunión de los pueblos indígenas -anárquicos pero autóctonos- o la incómoda nacionalidad lusitana de Viriato, bien podría incluirse la representación antigua de los idílicos héroes hispanos como viles salteadores; en la práctica, como ocurre con el resto de connotaciones negativas de los clásicos respecto a estos pueblos, su naturaleza salvaje y ladrona quedaría eclipsada por las alabanzas a su entrega y resistencia guerrera frente a un enemigo más numeroso y más fuerte. En cualquier caso, para cuando ese mito se consolidara como referente patrio en su forma definitiva a lo largo del siglo XIX, la figura del humilde bandido arremetiendo contra el imperio ya contaba con un nuevo y esencial referente: la Guerra de Independencia. Con el impacto napoleónico y la consolidación del liberalismo, tanto en España como en el resto de Europa, surge como concepto idealizado por antonomasia el de una resistencia popular y guerrillera frente al sometimiento extranjero y tiránico; rebeldía nacional que es vista desde un esencialismo histórico que la entronca con la resistencia a la conquista romana de hispanos, germanos, galos o britanoceltas, cuya fuerza subversiva permanecería latente en el espíritu de sus descendientes. Así el modelo previo adquiere nuevas connotaciones en función del nuevo contexto ideológico, reforzadas a su vez por la exaltación del naturalismo y primitivismo propia del Romanticismo ${ }^{27}$ y bebiendo, en algunas de sus formas, del universal arquetipo literario e ideológico del buen ladrón justiciero ${ }^{28}$ que, en nuestro caso, siempre se habría acoplado bien en el Viriato cínico-estoico caritativo que rechazaba para sí las riquezas ${ }^{29}$.

26 Sirvan como ejemplo Diod. V 34. 6-7; Liv. XXV 7, XXVIII 22 y 32, XXXIV 21; Plut. Sert. 14, Mario 6; vid. García Moreno, L. A. (1988), "Hispaniae Tumultus. Rebelión y violencia indígena en la España romana de época republicana”, Polis 1, pp. 81-107; Gómez Espelosín et alii, op. cit., pp. 124-125; Vallejo Girvés, M. (1994), "El recurso de Roma al bandidaje hispano", Espacio, Tiempo y Forma. Serie II: Historia Antigua 7, pp. 165-173.

27 Wulff (2007), op. cit., pp. 19-21.

28 Hobsbawm, E. ([1969] 2001), Bandidos, Barcelona: Crítica.

29. Hay quien ha visto agudamente en Viriato a un "Robin Hood protohistórico", Sánchezz ISSN: 1989-9289 
Como se adelantaba, este mito del guerrillero anti-imperialista volvería a reinventarse en las postrimerías del siglo XIX de la mano de J. Costa y su pionera interpretación socioeconómica de la Historia de España, dando una nueva vuelta de tuerca al manido tópico. En el capítulo "Cuatrería y Abigeato" de su inconclusa obra ${ }^{30}$, luego revisado en una conferencia leída en 1895 con revelador título: Viriato y la cuestión social en España en el siglo II antes de Jesucristo ${ }^{31}$, Costa desarrollaba su particular visión del bandolerismo prerromano en concreto y de las motivaciones de los enfrentamientos con Roma en general. Rompiendo con la clave tradicional y las trasnochadas exaltaciones nacionalistas, profundiza por primera vez en lo que considera las causas últimas del fenómeno, su articulación estructural de fondo, explicando la cuestión desde la problemática económica y social de estos pueblos. Según él, el bandolerismo, como el mercenariado o la servidumbre, no son más que válvulas de escape a una situación de miseria y sumisión, resultado de la imposición de las aristocracias sobre las tradicionales formas de vida indígena; la interesada intervención romana no hará sino agravar la situación, desencadenando las iras de las masas de desposeídos que se levantan en armas.

No cabe duda de que pervive en Costa un halo de romanticismo en su visión del pasado: "érales forzoso elegir entre la libertad o la tierra, entre morir libres o morir esclavos" ${ }^{2}$, al igual que una rémora esencialista contra la que lucha: "mas no todo era efecto de la guerra, sino más bien propensión heredada y que venía de muy lejos en la raza", lo que pronto desdice ${ }^{33}$. Pero la visión indudablemente idealizada que tiene de la realidad prerromana es ciertamente distinta a la del nacionalismo recalcitrante y patriotero del que reniega y al que critica duramente ${ }^{34}$; para él la resistencia hispana no es una defensa de la nación, sino una revuelta social:

\section{El desconocido analista de quien Diodoro sículo} bubo de tomar el sabido retrato de nuestro béroe entrevió como en una lejanía confusa la significación ideal de aquella gloriosa personalidad diciendo que "twvo en cuenta de patria la libertad" (...), y esto es lo cierto, pero no la libertad civil, diríamos a la romana la condición de ingenuo, como si bubiese nacido siervo; menos aún la libertad politica a estilo de la de nuestro tiempo, esa libertad abstracta proclamada por el liberalismo doctrinario (...); sino aquella otra que tiene en clase de garantia y de coeficiente la independencia personal fundada en la posesión de los instrumentos de trabajo: éste

Moreno (2002), op. cit., p. 146.

30 Costa Martínez, J. (1891-1895), Estudios Ibéricos, Madrid, pp. XXXIX-LIV.

31 Id. (s. a.), Tutela de los pueblos en la Historia, Madrid, pp. 1-53, especialmente 23 ss.

32 Costa (s. a.), op. cit., p. 28

33 Cita en Costa (1891-1895), op. cit., p. XLIII, negada en Id., (s. a.), op. cit., p. 27.

34 Costa (s. a.), op. cit., pp. 8-9 y 12, especialmente. 
fue el ideal de su vida; ésta su aspiración y el objetivo de sus admirables campañas ${ }^{35}$.

De su interesantísima conferencia se desprende con nitidez que no hay intención alguna de identificar en Viriato a un fundador de la nación, sino más bien a un emancipador de las clases oprimidas de su tiempo, ya fuera contra Roma o contra las aristocracias autóctonas ${ }^{36}$ : un "revolucionario de los tiempos modernos injerto en un héroe de Homero (...); un libertador del pueblo avasallado por la nobleza capitalista" ${ }_{37}$. El viejo mito se extrae de su molde nacionalista liberal para trasladar al pasado las inquietudes por los problemas sociales y económicos de una España en crisis y transformación. En absoluto esto supone una desmitificación de la heroica resistencia de pastores y bandidos; los estereotipos heredados son en el fondo idénticos, sus virtudes y méritos heroicos siguen siendo igualmente exaltados, la identificación del autor con las motivaciones y principios ideales de aquéllos es la misma, se trata de la aplicación de un mismo tópico a un modelo utópico bien distinto, el del espíritu progresista de la nueva intelectualidad regeneracionista.

En la interpretación estructural del fenómeno, una cuestión íntimamente ligada con la del bandolerismo, no por su ligazón antigua, sino en su reinterpretación contemporánea, es la del manido colectivismo agrario de los vacceos ${ }^{38}$. Siendo un tema ciertamente concreto, su importancia como fenómeno historiográfico y su justificación en estas líneas radica en que representa, en mi opinión, un interesante ejemplo complementario en lo que concierne a los mecanismos de transmisión de los estereotipos antiguos: hasta ahora hemos tratado auténticos topoi literarios que, reiterados en toda o buena parte de la historiografía grecolatina, se perpetuaron por distintas vías en el imaginario moderno; por el contrario, éste es un caso de formación plenamente contemporánea de un tópico que no existió en la Antigüedad, ya que, de hecho, paradójicamente, tan sólo se conserva sobre este tema un

35 Id., (s. a.), op. cit., pp. 9-10.

36 Costa (s. a.), op. cit., p. 39.

37 Id., (s. a.), op. cit., p. 11

38 Para las últimas revisiones del tema, con su estado de la cuestión vid. Salinas de Frías, M. (1989), "Sobre las formas de propiedad comunal en la cuenca del Duero en época Prerromana", Veleia 6, pp. 103-110; Id. (1990), "El colectivismo agrario de los vacceos: una revisión crítica", en Actas del I Congreso de Historia de Zamora, vol. II, Zamora, pp. 429-435; Id. (2004), "Los Vacceos en la Biblioteca Histórica de Diodoro de Sicilia", Conimbriga 43, pp. 47-62; Id. (2010), "El colectivismo de los vacceos, entre el mito y la realidad histórica", en Romero, F. y Sanz, C. (eds.), De la Región Vaccea a la Arqueología Vaccea, Valladolid: Centro de Estudios Vacceos "Federico Wattenberg" de la Universidad de Valladolid, pp. 105-121; Sánchez Moreno, E. (1998-1999), La agricultura vaccea: ¿Un topos literario? Ensayo de valoración", Memorias de historia antigua 19-20, pp. 81-110; Gómez Fraile, J. Mª (2001), Los celtas en los valles altos del Duero y del Ebro, Alcalá de Henares: Universidad de Alcalá, pp. 181185. 
exiguo fragmento en las fuentes. Estamos, por lo tanto, ante un interesante fenómeno de sobredimensión del dato antiguo en el origen de un tópico moderno en el que la utopía socialista de Costa vuelve a tener un papel clave.

El fragmento en cuestión (Diod. V 34. 3) hace una breve alusión a la costumbre vaccea de dividir la tierra cultivable cada año para luego repartir las cosechas, una práctica que, de ser contravenida, conllevaba la pena de muerte. Aunque éste es un unicum en la historiografía clásica, se han vertido sobre él verdaderos ríos de tinta en la investigación moderna. Se ha presupuesto que la procedencia de esta información hay que adscribirla a Polibio, de lo que se deriva, por tanto, que la observación directa -si la hubode estos peculiares usos vacceos, se inscribiría en el contexto de alguna de las campañas militares en las que participó Escipión Emiliano en estos territorios (150 y 134 a. n. e.), es decir, que el relato debería considerarse dentro de un estado crítico de guerra en el que, si este sistema productivo se dio, bien pudiera constituir una respuesta más o menos excepcional a las necesidades de abastecimiento de suministros a la resistencia numantina ${ }^{39}$. Yendo más allá, superando los denudados esfuerzos por buscar la historicidad del texto, resulta más que plausible interpretarlo como una mera invención o, cuando menos, una generalización exagerada de Diodoro, que parece proyectar en los vacceos ciertas concepciones utópicas de tipo estoico entre las que la ausencia de propiedad privada es un elemento recurrente, lo que encajaría bien en esta primera parte de su obra, de importante contenido mítico y fabuloso ${ }^{40}$. En cualquier caso, estamos ante un relato demasiado aislado e impreciso como para sacar de él -como ha sido habitual-, conclusiones que resultan anacrónicas, generalistas y especulativas ${ }^{41}$. No obstante, esta lógica reflexión se demandaba en su momento como absolutamente necesaria en tanto que el tema, por débil que sea su respaldo documental, ha sido un verdadero tópico en la historiografía contemporánea ${ }^{42}$.

Aunque hubo menciones previas al tema, de limitada repercusión, gran parte del mérito de convertir ese humilde y contaminado fragmento en un auténtico tópico debe ser atribuida a los esfuerzos idealistas de Costa. De forma recurrente en su obra histórica y económica ${ }^{43}$ insertará la cuestión

39 Sánchez Moreno (1998-1999), op. cit., pp. 85-88.

40 Gómez Fraile (2001) op. cit., pp. 184-185; Salinas (2004), op. cit., pp. 56-62; Id. (2010), op. cit., pp. 111-118.

41 Salinas (1989), op. cit., pp. 109-110; Id. (2010), op. cit., p. 118, especialmente; Sánchez Moreno (1998-1999), op. cit., pp. 85-88; Gómez Fraile (2001), op. cit., p. 185.

42 Un exhaustivo repaso historiográfico de la cuestión, en Domínguez Monedero, A. J. (1988), "En torno a algunos aspectos socio-económicos de la cultura vaccea: estado de la cuestión y nuevas aportaciones", Caesaraugusta 65, pp. 35-53; vid. también, sobre los vacceos en general, Sánchez Moreno, E. (2010), "Los vacceos a través de las fuentes: una perspectiva actual”, en Romero, F. y Sanz, C. (eds.), op. cit., pp. 65-103.

43 Costa (s. a.), op. cit., pp. 13-15; Id. ([1898] 1983), Colectivismo agrario en España. Tomo II, Zaragoza: Guara, pp. 173-175; Id. (1917), La religión de los celtíberos y su organización política 
del colectivismo vacceo, haciéndolo partícipe de su representación idílica de las igualitarias sociedades indígenas sometidas, propósito para el que la célebre cita de Diodoro no podría ser más pertinente. Negando la validez de ciertas especulaciones y comparaciones previas, defiende una lectura directa del texto, aunque no se priva de considerarlo en los términos de socialismo o comunismo agrario, de conectarlo con la riqueza productiva de los vacceos atestiguada en las fuentes o de identificar su pervivencia en las formas de producción tradicionales de ciertas zonas de la cuenca del Duero que serían abolidas con las desamortizaciones contemporáneas ${ }^{44}$. Según el reformista, la resistencia de este pueblo a las invasiones celtas habría impedido que éstos pudieran imponerse sobre ellos por completo dando lugar a una sociedad mixta, de manera que sus tradicionales formas de producción comunal pudieran conservarse, con altibajos, en el transcurrir de los siglos; lo contrario habría ocurrido con los pueblos colindantes, como los celtíberos, cuyo ancestral disfrute comunal de la tierra sería anulado por el yugo celta. Así contrapone directamente este sistema productivo socialista conservado por los vacceos con el régimen oligárquico de propiedad privada impuesta por la fuerza por celtas primero y romanos después, paradigmas del sometimiento y la esclavitud de las masas campesinas por las élites. Este mismo proceso de jerarquización y privatización de la riqueza sería el que minara las ancestrales formas de organización social indígenas de tipo gentilicio, abocando a estas comunidades a una feudalización socioeconómica y política que arrastraría a la mayoría de la población a la miseria ${ }^{45}$.

No es difícil identificar, en este razonamiento, una derivación con patente histórica de la idealización rousseauniana del igualitarismo primitivista heredada en el pensamiento socialista. El colectivismo vacceo, además, le sirve a Costa como arma arrojadiza contra las desamortizaciones decimonónicas, a las que critica en su defensa del disfrute comunal de los recursos como solución a los problemas económicos y sociales de España; para esto acudió sistemáticamente a anacrónicos referentes históricos y etnográficos ${ }^{46}$ entre los que el caso vacceo representaba el horizonte más antiguo. Así, en el marco explicativo general de la resistencia indígena contra Roma entendida como lucha de clases, se servirá del pertinente apunte del historiador sículo para volcar sobre los vacceos su visión utópica de los primitivos hispanos, y hacer de ellos, en última instancia, un trasunto del sistema socio-económico del futuro que defiende:

y civil, Madrid, pp. 82-85.

44 Algunas de estas zonas ni siquiera están situadas en territorio vacceo (Salinas (2010), op. cit., p. 107).

45 Costa (s. a.), op. cit., pp. 13 ss., p. ej.; un repaso a la cuestión del sistema gentilicio en Gómez Fraile (2001), op. cit., pp. 225-262.

46 Garayo Urruela, J. M (1998), “Colectivismo agrario y regeneración política y social de la democracia liberal sobre bases campesinas en Joaquín Costa", Anales de la Fundación Joaquín Costa 15, pp. 141-168. 
Que todos aquellos que tienen las tremendas responsabilidades del gobierno; que todos aquellos en cuyas manos está la llave del porvenir, tomen lección en esa escuela; que comparen los frutos de la economía pública de los vacceos con la de los celtíberos y lusitanos; qué interroguen a Sempronio Graccho y Octavio Augusto; y midan los ríos de sangre que costó la dureza de Galba y de Tito Didio; y ahorren terribles experiencias a los presentes, tomándolas de lo pasado, haciendo de la historia lo que Cicerón quería que fuese: una maestra de la vida ${ }^{47}$.

\section{LA NATURALEZA DEL ARTIFICIO}

Ni es el cometido propuesto ni resulta posible repasar aquí el devenir de estos conceptos en la historiografía posterior. Resulta obligado, no obstante, destacar la trascendencia de estos pioneros planteamientos. En cuanto a la cuestión del colectivismo vacceo, ésta se convertirá en un tema central en la investigación sobre la protohistoria hispana, y los esquemas básicos de Costa se reproducirán prolíficamente, ya sea en la dimensión socioeconómica de su modelo explicativo -junto al otro gran tópico del igualitarismo prerromano, el del sistema gentilicio- de forma especialmente directa en la perspectiva materialista encabezada por M. Vigil ${ }^{48}$, como en la idea de la pervivencia o resurgimiento etnográfico del fenómeno en las tradiciones de la cuenca del Duero $^{49}$; nociones enviciadas que hasta hace relativamente pocos años no han sido desterradas de la historiografía.

Por su parte, una pervivencia híbrida -podríamos decir- del mito del bandolero hispano de nobles vocaciones será el que sobreviva a Costa: como se ha dicho, el esencialismo nacionalista más conservador pasará por encima de los esfuerzos por cambiar viejos paradigmas -de los que Costa no es el único representante-, reactivándose durante el franquismo; no obstante, la interpretación socioeconómica del fenómeno quedará ya plenamente instalada en la historiografía seria, constituyéndose un nuevo hito fundamental en la obra de A. García y Bellido ${ }^{50}$, donde se imbrican a la perfección las preconcepciones esencialistas de viejo calado y las reinterpretaciones en clave económica iniciadas por Costa. En el plano divulgativo, en regresión a la España del Antiguo Régimen, la imagen de

47 Costa (s. a.), op. cit., p. 53.

48 Vigil Pascual, M. (1963), "Romanización y permanencia de estructuras sociales indígenas en la España septentrional”, en Boletín de la Real Academia de la Historia 52, pp. 225-233 [reeditado en Prieto Arciniega, A. (ed.) (1977), Conflictos y estructuras sociales en la Hispania Antigua, Madrid: Akal, pp. 129-138], como ejemplo significativo.

49 Cabo Alonso, A. (1956), "El colectivismo agrario en tierra de Sayago", Estudios geográficos vol. $17, \mathrm{n}^{\circ} 65$ (noviembre), pp. 602-603.

50 García y Bellido, A. (1945), "Bandas y guerrillas en las luchas con Roma", Hispania 21, pp. 547-605 [reeditado en Prieto Arciniega, op. cit., pp. 13-60]. 
miserables salteadores arremetiendo contra Roma volvía a ser incómoda de acoplar en los preceptos imperialistas del nacional-catolicismo, siendo además fácilmente identificable con la guerrilla antifranquista. Por ello, esta dimensión de los héroes, como la de su problemática nacionalidad, propiciará su ambiguo y contradictorio tratamiento en la historiografía plenamente adepta al régimen; así, la consideración de Viriato oscilará entre la del ajeno bandolero lusitano y la del glorioso caudillo españo ${ }^{11}$.

El anquilosamiento, la reiteración y la propia identificación con el régimen franquista tenderán a agotar el mito, fuertemente dañado a partir de la década de los 60; ya superado el bache, estamos viviendo en los últimos años un auténtico renacimiento popular de estos mismos clichés idealizantes del pasado prerromano, en parte por nociones educativas heredadas y por el resurgir de los referentes nacionalistas en la Europa comunitaria $a^{52}$, en consonancia, desde luego, con el auge y la explotación comercial en los últimos años del género histórico, muy patente en la industria editorial, la televisión o Internet ${ }^{53}$.

El sondeo que se ha llevado a cabo en estos constructos culturales, una pequeña muestra de sus múltiples facetas y derivaciones, nos demuestra, en primer lugar, hasta qué punto la reconstrucción idealizada del pasado primitivo ha estado presente en la configuración ideológica y cultural de las identidades modernas y contemporáneas: sobre los hombros de estos pueblos se volcaron necesidades de legitimación imperialista, anhelos de identidad nacional o utópicas visiones sociales, maleando a placer un reflejo

51 Alvar Ezquerra, J. (1997), "Héroes ajenos: Aníbal y Viriato”, en Alvar, J. y Blázquez, J. $\mathrm{M}^{\mathrm{a}}$. (eds.), Héroes y antibéroes en la Antigüedad clásica, Madrid: Cátedra, pp. 137-153; García Quintela (1999), op. cit., p. 182. Semejante fenómeno observamos en Portugal en la década de los 70, cuando el referente de Viriato decaiga por el fácil paralelismo del bandolerismo lusitano y la resistencia guerrillera a la que se enfrentaba el país en las guerras coloniales (Guerra y Fãbiao, op. cit., pp. 21-22).

52 Guerra y Fãbiao, op. cit., pp. 9-10; Iguacel de la Cruz, P. (2008), “Tartessos: el mito en lenguaje de cómic", en Castillo, $\mathrm{M}^{\mathrm{a}} \mathrm{J}$. (coord.), Congreso Internacional "Imagines", La Antigüedad en las Artes escénicas y visuales, Logroño: Universidad de La Rioja, pp. 655-657.

53 Sánchez Moreno y Aguilera, op. cit. Como ejemplos recientes de lo primero se pueden citar, entre otros muchos, Numancia (J. L. Corral, 2003, Barcelona: Edhasa), La voz de Lug: la epopeya del pueblo astur (T. Martinez de Lezea, 2003, Madrid: Maeva) o El último soldurio (J. Lorenzo, 2005, Barcelona: Planeta), sin mencionar la producción divulgativa (muy ilustrativo es el título de la obra de M. Pastor (op. cit.): Viriato. El héroe hispano que luchó por la libertad de su pueblo). En cuanto a la TV, la reciente producción de Antena 3, Hispania: la leyenda (vid. Manzanera, L. (2010), "Viriato: ique viva Hispania!”, Clí 110, p. 106; Quesada Sanz, F. (2011), "Un héroe para Hispania: Viriato", La aventura de la Historia 148, pp. 46-51), es una extraordinaria muestra de la pervivencia de viejos tópicos, entre los que se encuentra la idealización de los modos de vida primitivos, la exaltación del honor guerrero hispano frente a la perfidia romana o la representación de Viriato como buen ladrón y ejemplar líder cínico-estoico. 
antiguo ya de por sí artificioso. Ejemplifican estas reflexiones, por otro lado, lo complejo de la transmisión de los estereotipos antiguos; podemos identificar fácilmente la transmisión "directa" de ciertos tópicos -como la heroización de la resistencia hispana-, siendo los mismos elementos positivos exaltados los de la imagen antigua y su versión anacrónica, más allá de todas las variantes y matices; pero, haciendo un ejercicio de abstracción, también podríamos adivinar procesos de transmisión "inversa", en tanto que un elemento proyectado desde la antigüedad como esencialmente peyorativo será soslayado, reconducido o reinterpretado de forma que se convierta en su versión moderna en motivo de virtud y orgullo: innobles bandoleros salvajes devienen en libertadores de la patria o loables revolucionarios; otros, como el colectivismo vacceo, nacen prácticamente de la nada, y noticias anecdóticas debidamente sobredimensionadas y dotadas de connotaciones que en realidad le son ajenas engendran tópicos antiguos que en realidad nunca lo fueron.

En todos estos procesos están interactuando de forma compleja el propio elemento antiguo y sus condicionantes, su trasmisión a lo largo de la propia literatura clásica, sus derivaciones y apropiaciones modernas y sus evoluciones y reinvenciones cientificistas contemporáneas, cargándose en todo el proceso de implicaciones emocionales, motivaciones y anhelos difíciles de definir y aislar, y que corremos el peligro de ver como frías y premeditadas manipulaciones ajenas a nuestras propias inquietudes; nada más lejos de la realidad. Sólo una reflexión deconstructiva y profunda nos desvela la complejidad interna del artificio, enseñándonos, a fin de cuentas, lo volátil de la naturaleza de los ideales. 
